\title{
The Transformation of Narrative in Mass Media
}

\author{
Ishanova A.K. \\ Doctor of philological sciences, professor of \\ L.N. Gumilyov Eurasian National University (Astana, Kazakhstan)
}

\section{Doi:10.5901/mjss.2013.v4n11p488}

\begin{abstract}
The following article addresses the problem of modification of media texts, seeking to borrow main external techniques of literary narrative, which lead to the emasculation of the verbal nature of information to the dominance of fragmentariness, mosaic fragmentation.
\end{abstract}

Keywords: Narrative, mediatext, media reality, transformation of media

In the era of the modern anthropological crisis, at the end of the first decade of the twenty-first century we can particularly evidently observe an epistemological break, in the faults of which there have appeared completely underground and different guidelines, policies, and together with them methods, techniques of representations of man and the world, that are most clearly manifested in the media environment of people's everyday life.

J. Habermas in his book "Shattered West" indicates, above all, the loss of the principles of "proper living", which a long time before determined the basis of Western culture.

The vital-cultural break-up, most clearly embodied in the mass media space, today allows us to observe the emergence of new media communication models - diary journalism, the blog-sphere, reality shows, an attempt to combine the radio and social networks, mixture of almost all genres of media in the Internet portals (the use of the popular technique of developability of genre forms from simple to complex), the so-called "mobile" journalism, "popular" journalism. But still the basis for new genres is verbal. However, there are new ways and methods of structuring the material associated with new features of interaction of art culture and mass media. "Capturing the reality" by the modern media, that is television, the Internet, social networks, is followed by an even more profound process of "creating a media reality". Modern mass media every year and decade win back more and more space and sphere of influence as a special type of culture and communication of the information society. Thus they become a significant mediator between society and the state, society and government. The modern media space is a complex phenomenon, and an ambiguous one. The transformation of mass media and informational challenges of post-modernistic civilization expose mankind to a dilemma searching for keys to the new reality and man's place in it.

Modern culture globally is going through hard times. A.Ya. Flier believes that it is time to rethink the concept, saying about the "blood thirst" of culture. In the age of nanotechnology and more and more accelerating technological revolutions and discoveries, less and less space is left for the human, human life is increasingly becoming worthless.

Even Rousseau, exploring the reasons for the collapse of ancient Greek civilization, came to a hardly comforting conclusion that the higher is the level of civilization, the immoral the society is.

Today we are witnessing a rapid change in mass media, where journalists have to find new forms and methods of work to compete with "traditional" journalism and immediacy of bloggers. But the same equally rapid changes are taking place in the movie, the rate of change is so great that researchers have noted the need to replace the word "movie" with a new phrase "film and new media". We must immediately explore these new processes, as the technological development of movie and media most directly influence the society, politics, culture, aesthetics, everyday life and existence of modern man.

If at the previous stages of the triumph of television and video the movie adapted itself to media conditions, now the things are more complicated. In the modern "digital" period the movie is not a medium any more and is neither an art form, it is a condition of vision and a condition of thought".

The philosopher and theoretician of the movie David Rodovik [3 P. 23] suggest that we should move from the word "movie" to a more correct definition "a moving image".

Modern society is a society of continuous signs without content, flashy signs of the urban landscape, pointing to 
the image, post-modernistic fuss of media space, but in all this we cannot find the main thing - sense. Neo-modern school, modern society, neo-feudalism, where, to which society is the world moving? Currently, researchers in the humanities insist on the relevance of such approaches to the study of culture as "openness-closedness", from these positions Kazakhstani culture in general discourse of public policy is rather moving to openness. The new anthropological turn, claimed as the dominant trend in the world of academic experience, is linked to fundamental changes in the principles of research of historical practices of knowledge and culture. Many scientists are attracted by the possibility of displacement of vector and focus of research from traditional inclusive patterns of social development toward a specific individual, which will contribute to a better understanding of the complex mechanisms of the functioning of society as a whole and a radical revision of the concepts of historical development. The rapid distribution of anthropological approaches in the post-Soviet space indicates to the extraordinary availability of this multidisciplinary direction in order to reconsider its dramatic past in the broader context of modernist culture. "The new anthropology of culture" is a dominant principle of the focus of studies of famous Russian scientists, in particular, of the magazine "New Literary Review".

With the development of the modern culture of Kazakhstan, all these new approaches are also relevant, but even in the era of overall globalizing media space there appear extremely important islands of originality and difference of cultural codes of perception and interpretation of texts, an abundance of modern media culture available today.

The current reality is that the space of media culture is gradually absorbing everything, including literature, cinema and many other kinds of art, all of which have traditionally been formed in particular and original ways.

Let us try to trace only a few trends of post-Soviet (Russian and Kazakhstani) mass media in terms of the poetics of narrative, principles of the formation of a media text, its effects and interpretations of the author and the readerspectator.

Literature, which had been occupying the dominant position in world culture in the previous century, now is somewhat pushed back by visual arts that are increasingly expanding their mass media space. Moreover, imperceptibly but surely, media culture increasingly claims to become a substitute for literature.

The entire human life is a continuous narrative, where the existence of the ancestors, parents, children, descendants is interwoven in the form of the most complex tangle with the history of the people, nation, civilization and the state. The story and the history of a kin, an individual in literature have always attracted people by the possibility of knowing the world and reality.

Modern traditional and new media in XXI century have started using the potentials of the narrative, especially not adhering to the classical canons of the genre of nature. On television, there are now numerous "female and male" stories. Stories about the mysterious and the unknown form the media basis of big television channels (TV-3, REN TV, and Russia), biographic series and stories about life and love of movie stars, judicial proceedings are shown as entertaining narratives. It would seem that there is nothing wrong in that, but even the shows, and sometimes the news now resemble a story or a series of stories. Namely in this way the program "Let them talk" by A. Malakhov (NTV, Russia) is arranged.

However, the narrative in the media sector is somewhat neutered, there is no core, commentary or final in it, and hence neither meaning no depth. This leads to the fact that media teaches the viewer to perceive virtual reality as the scene of a routine murder, violence, gratuitous cruelty. (You may recall one of the programs of "Let them talk" about a young mother who murdered her own newborn baby).

Thus, media-narrative using an external form of literary narrative, in fact destroys its internal structure and functional significance. Saturated the screen with different stories, the media-narrative seeks in some way to replace the elite movie industry, literature and other kinds of art which are very poorly represented on the Kazakhstani TV channels.

There is an especially clear manifestation of the superficial use of certain narrative techniques in programs dedicated to the Russian cinema stars departed from the life (L. Gurchenko, N. Mordyukova and other idols of millions of viewers). A too straightforward scheme of the story, narrowing or even a complete lack of psychological canvas of history, internal lamination of life impoverish or, perhaps, even distorts the line of the existential narrative, bringing it to the scheme, inscribed by the author-journalist. Although, by the way, it should be noted that the Kazakhstani television channels do not even attempt to pay their respects to many well known departed workers of culture and literature at least in such manner. There are two trends in the TV programs of this kind. Some of them build their plots on sensation, secrecy, and mystery, for example, there are numerous similar stories about the causes of death of the actor Porohovschikov and his wife, whose deaths are associated with mystical secrets of the ancient mansion they lived in. Other stories are mono-planned, biographical; their narrative is based on a simplified linear scheme, as the stories about famous people on the Kazakhstani TV channels.

Literary and media narratives differ in terms of fiction and verisimilitude. Many medianarratives claim to credibility 
while a literary narrative is based more on fiction.

Today, no one denies that the literary narrative is useful in many ways: we get "surrogate experience" with it, expand our "emotional horizons", get to know ourselves, and borrow pleasure. But still there is a viewpoint that literature is unable to make us more moral. Such a categorical proposition could appear only in the epoch of predominance of mass media culture.

Today the poetics of medianarrative is determined by post-modernistic hybridity, a mixture of styles, virtuality, irrationality, mosaic fragmentation, where the viewer is constantly taught neither to analyze not to critically reflect, but to thoughtlessly "consume" a media story-event.

Particularly noteworthy are the programs that are built on the following principle: "The more blood, the better". If previously the largest media forum energetically discussed the possibility and need to broadcast scenes of violence and blood, now media writers have moved from words to deeds. TV screens are literally inundated with stories about rapists, maniacs, murderers, in detail. There is a detailed demonstration of ways and forms of violence. Owners of television channels are trying to keep audience at the screen as longer as possible, and this audience gradually gets used to everything. In such programs the narrative is altogether replaced by visually shocking photographs, outright theater and game productions. There is a particular success in the development of this television format achieved by the Kazakhstani TV channel "Commercial Television Channel" (CTCh) with its program "Raider" which is popular among numerous domestic audiences.

The general trend in many television programs was to aim at the laconic verbal commentary; an allusion to the story is sometimes replaced by simplicity and primitiveness, the funny and the ironic border on vulgar tabloid. Television announcers let themselves pose smiley faces and play vulgar jokes on each other, using incoherent phrases (about a dirty sweater, a desire to get big salaries, etc.).

Many television programs dominate over fragmentation. If the entire narrative consists of short clips, the narration is constantly broken into smaller parts, connected by joints of editing. A large fragmentation refers to both the organization of the picture (and the audience sight) and the arrangement of plots. In general, in the program you find resistance to "words", to the verbal nature of information. The choice is made either in favor of rhythm, which subjugates the content, or for the benefit of visibility, objectivity.

Initially, the classical literary narrative strove to seek the truth, the modern medianarrative which is in pursuit of sensationalism and entertainment, is defiantly far from it. There arises the question: How long you can use the external frame of the narrative without any damage to the plot, which is closely linked with the narrative? Perhaps this break in the chain of links of structures is hiding the failure of many modern native TV series?

\section{References}

Habermas J." Shattered West". - Moscow, "The Entire World" Press, 2008.

Flier A.Ya.. Non-cultural Functions of Culture. Outlines. - Moscow, MSUCA Press, 2008.

Samutina M. Transformation of an object as a challenge to the science of the movie // New Literary Review, 2011 № 10 